\title{
Developing Visual Perception as a Stimulator of Artistic Activities of Children
}

\author{
Urszula Szuścik \\ University of Silesia, Poland \\ E-mail address: ulaszus@ @oczta.onet.pl
}

ARTICLE INFO

\section{Keywords:}

Visual perception

Children

Stimulator

Artistic activities

Process

Creativity

Article history:

Received 25 May 2015

Received in revised form 14 October 2015

Accepted 20 October 2015

ISSN: 2354-0036

DOI: 10.1515/ctra-2016-0003
A B S T R A C T

I would like to present research in the field of art - specifically, in the artistic education of younger school children. The natural pedagogical experiment consisted of carrying out an art education programme aimed at developing the visual perception of children with regard to visual qualities, i.e. colour, line and solid representations. In the first part of experiment the children learned about these basic visual qualities and produced free interpretations of them. In the second part of the experiment the artistic problem of contrast in the learned visual qualities appeared. During the third part of the experiment children perceived the familiar qualities in relative relations. As visual perception determines the character and quality of artistic activities in children in such a significant way, it seems worth trying to revise the system of developing their artistic activities that has been used so far in art education.

\section{INTRODUCTION}

The activities of children, which are characterized by originality, searching, an attempt to imitate, dramatic verbal and non-verbal behaviour, are regarded as creative behaviour. They develop the will to create, imagination, cognition, motivation and desire to search for the essence of things known and unknown to the child. Play and all forms of its creative activity, including artistic activities, are manifestations of creative behaviour. The artistic activities of children are also peculiar manifestations of play. The stages of its development are characterized by such features of play as, more or less inspired spontaneity, directed, time controlled, more and more goal oriented, which form the work of the child and its result, and develop the ability to plan creative work. These activities give the child emotional and cognitive pleasure and at the same time ensure the development of its perception, general agility, thinking and imagination.

\section{ASSUMPTIONS OF THE RESEARCH}

Visual perception, which stimulates the artistic creations of the child, is an essential factor 
contributing to the development of the child, motivating him/her to get to know him/herself and to develop his/her abilities. It is connected with the influence of a wide range of stimuli, including stimulation of his/her visual perception in a planned but open way, which means that the child selects and shapes them on the basis of his/her needs. The child develops his/her skills in the field of perceptive knowledge, his/her ability to use this knowledge in artistic activities, which leads to familiarity with with artistic techniques and means of expression. The child becomes free in the act of creation. He/she decides about the act and about the form of his/her composition. He/she begins to ask questions, to look for answers, to experiment and this leads to independent and creative thinking. $\mathrm{He} / \mathrm{she}$ creates his/her own creative, not merely reproducible world. These were some of the assumptions behind the studies carried out in the field of developing visual perception as a stimulator of artistic activities of children. I would like to present the hypotheses and results of a pedagogical experiment in the field of art education for younger school children - 7 to 9 years old. ${ }^{1}$ The existing psychological and pedagogical literature on the development of artistic creativity in children does not give unequivocal answers with regard to factors concerning this development.

The psychological works of Baley (1948), Witwicki (1948) and Szuman (1927) provide knowledge on the development of perception in children and their sensitivity to colours, shapes, sizes and the proportions between them; however, they do not indicate any connection with the artistic representation of the perceived objects. In the works of art educationalists, there are also only general remarks on this subject, perhaps because of the lack of methods for studying the relationship between vision and artistic activities. This is one of the reasons for choosing this as the subject for research. A second reason results from my experience in working with children. I have attempted to identify agents involved in the development of artistic activities in children and, at the same time, of their general development. As a result of observation and analysis of the artistic activities of younger school-age children and pilot studies carried out earlier, I formulated the hypothesis that the factor determining the development of artistic activity in children is the competent shaping of their visual perception.

I differentiate between the terms: artistic activity and artistic creativity of children. Artistic activity is the artistic action of children conditioned by their psychological and physical development, specific to their age. However, the artistic creativity of children

\footnotetext{
${ }^{1}$ I have described these experimental and theoretical considerations in the book: Szuścik: Kształtowanie percepcji wzrokowej jako stymulator działań plastycznych dziecka. UŚ Filia w Cieszynie. Cieszyn 1999. (Developing visual perception as a stimulator of artistic activities in children).
} 
is the result of their experience and visual awareness in the field of learning and experiencing material and the technical possibilities of various techniques. This is demonstrated in the form of their artistic work which goes beyond the characteristics of work typical for a given age of children and accepted in the psychology of creativity.

I assumed that developing visual perception in the field of arts on specified visual qualities is a process involving distinguishing, recognising and naming phenomena and objects found in the range of perception and as presented in artistic work. These qualities are: colour, line and solid representations. I assumed that there is a relationship between the number and quality of visual stimuli, the quality of visual perception and value of the artistic creations of children. The following research hypothesis was formulated: Shaping visual perception with "visual qualities" causes the development of artistic creation in children in the early school age period and contributes to forming artistic activities as a form of independent and conscious activity. The natural pedagogical experiment consisted of carrying out an art education programme aimed at developing visual perception in children with regard to "visual qualities", i.e. colour, line and solid representations. Only perceptual ability shaped in this way stimulated the artistic activities of children.

\section{METHOD}

The programme of the experiment included 45 artistic exercises. It consisted of three parts. Each part comprised 15 exercises in each form (the first, second and third). Particular parts included five exercises for colours, lines and solids. These visual qualities constitute children's artistic "ABC". Exercise 5 was the control task for all the groups (i.e. experimental group and control group). I ran the classes in the experimental group myself, as an art teacher. Control exercises (no 5) in the control group were conducted by a teacher of this subject, who ran the remaining classes in accordance with the current programme of art education in the first forms of primary school. The level of difficulty of artistic exercises was incremental.

The artistic tasks set for children were artistic problems, which the child solved individually through developing his/her visual perception of a given visual quality. In the perceptual visual model, the visual quality was a set of visual stimuli. The perceptual model (standard) was a record of the idea of classes and did not represent objects known to children earlier. Thus abstract, and at the same time, open arrangements were created; this gave children the possibility for creative perception and artistic interpretation of the objects.

A form of multi-code transmissions was used in the experiment. After Bruner (1978), the following codes were distinguished:

- icon codes - experiments with arrangements of visual qualities occurring not only in na- 
ture, but also supplying children with certain perceptual standards;

- symbolic codes - descriptive, verbal categories concerning differentiation in the scope of visual qualities;

- enactive codes - planned manipulations connected with painting, drawing and sculpture.

Instructions for classes were important elements that enabled children to perceive abstract perceptual models in their categories of mental development, on the level of concrete operations. I wanted a perceived perceptual model to stimulate children to undertake an independent search of solutions in the field of problems with regard to colour, line and solid representations and to set free all their possibilities, of which they were not aware.

In considering how to translate the multitude of perceived visual qualities, abstract in character, into values that were close, well-known and individually experienced by each child, I asked myself - what has got the qualities of being multitude, open and emotionally significant? - a family, for sure. The family, that is to say multitude. Each child has his/her imaginary and emotional picture of a family. It is also open because of the great variety of experiences of children. Therefore I used the word "family" to name the multitude of colours, lines and solids perceived by children. Children perceived in the perceptual models, that is in compositions consisting of colours, lines and solids - for individual exercises - families of colours, then families of lines and families of solids. It turned out that this semantic key for translating abstract visual qualities into understanding and interpretation of the artistic tasks by children was clear to them.

In the painting exercises, the children painted on big sheets of paper, with flat bristly brushes no 20, with poster paints, using palettes for mixing colours. As for the painting technique, the children did not use white and black colours, but they tried to achieve various colours by mixing the colour with other chromatic colours in order to obtain the reds identical with those they perceived.

In the drawing exercises the children drew on big sheets of paper with brushes of various shapes and thickness.

In the sculpture exercises they were engaged in clay modelling.

The artistic activities of the children consisted of free activity and artistic interpretations of the perceived "visual qualities" I had prepared.

In the first part of the experiment, the children learned about the basic visual qualities and produced free artistic interpretations of them. These exercises were aimed at the shaping and developing of conscious perception and artistic experience in the range of: colour (visual perception of chromatic qualities of the various paleness of colours), lines (visual perception of the quality of lines of various shapes, length, width, directions) and 
solids (visual perception of the quality of solids of various shapes, thickness, sizes).

In the first class these were:

- painting exercises:
ex. 1 - red colour family ${ }^{2}$
ex. 2 - blue colour family ${ }^{3}$
ex. 3 - yellow colour family
ex. 4 - green colour family
ex. 5. - control exercise on the subject: "Red and green balloons at a ball with yellow and blue balls"4

- drawing exercises:
ex. 1 - straight lines family
ex. 2 - curved lines family
ex. 3 - broken lines family
ex. 4 - compound lines family

ex. 5. - control exercise on the subject: "The world of the stick insects"

- $\quad$ sculpture exercises:
ex. 1 - cuboid solids family
ex. 2 - rounded solids family
ex. 3 - cylindrical solids family
ex. 4 - pyramidal solids family

ex. 5. - control exercise on the subject: "A castle"

In the second part of the experiment the artistic problem of contrast in the above learned visual qualities appeared:

for colour - visual perception of arrangements composed of contrasting chromatic sets;

for lines - visual perception of the quality of contrasting lines;

for solids - visual perception of arrangements of contrasting solids

In the second class the perceived "families" from class I appeared in contrasted compositions [arrangements]:

- painting exercises:

\section{ex. 1 - families of red and green colours ${ }^{5}$}

\footnotetext{
${ }^{2}$ In class I in the painting exercise the children painted the perceived "red colour family" - they perceived 13 reds, different in respect of paleness and saturation. I did not tell them whether they should paint all the reds they saw - anything they painted was OK. I did not tell them whether the reds should be circles, squares or any other shapes; the children could have also painted red people, when they heard the word "family", but this did not happen. This demonstrates that the task instructions were properly formulated. Each child individually decided about the shape, size and number of reds in his work on the basis of the perceived colours. In the perceived model there was not any white background. I did not draw their attention to white backgrounds in their work on purpose, hoping that along with the development of their artistic perception and experience they would cover the whole sheet of paper with the perceived colours, without any white patches. My assumption proved correct, as in the second exercise, when the children were painting "the family of the blue colour", most of them covered the whole surface of the paper with blue colours, and leaving any white background.

3 The children perceived 13 blues, 13 yellows and 13 greens different in respect of paleness and saturation and painted them.

${ }^{4}$ Exercise 5 was a control exercise checking the so far acquired visual and artistic experiences of the children. They painted their work without a perceptual model. The same exercise was also conducted in the control group, in which the children had not received any perceptual models. The children from the experimental group painted interesting work, abstract in character, while the children from the control group painted work typical for school children of that age: the base line, the sky line, personification of balloons (painted eyes, lips, noses, eye-lashes), decorations of the ball room, poor colouring of the work. The children from the control group treated the topic of the classes in a descriptive way ${ }^{5}$ In form II, while painting, most of the children tried to compose their painting works to represent the arrangement of the perceptual model perceived in class.
} 

ex. 2 - families of blue and yellow colours
ex. 3 - families of white and black colours
ex. 4 - families of warm and cold colours
ex. 5. - control exercise on the subject: "The battle of colours in Ungo world"

- drawing exercises:

ex. 1 - families of long and short lines

ex. 2 - families of thick and thin lines

ex. 3 - families of curved and broken lines

ex. 4 - families of straight and compound lines

ex. 5. - control exercise on the subject: "The line in space"

- sculpture exercises:

ex. 1 - families of large and small solids

ex. 2 - families of rounded and cuboid solids

ex. 3 - families of conical and cylindrical solids

ex. 4 - families of concave and convex solids

ex. 5. - control exercise on the subject: "The house of a robot and the house of a magician"

During the third part of the experiment the children perceived the familiar visual qualities in relative relations.

for colour - visual perception of chromatic qualities in a variety of colour surroundings;

for lines - visual perception of lines in various surrounding of lines;

for solids - visual perception of solids in a variety of arrangements.

In class III the perceived families of visual qualities appeared in relative compositions:

- painting exercises

ex. 1 - red colour surrounded by red, green, blue and yellow colours ${ }^{7}$

ex. 2 - green colour surrounded by red, green, blue and yellow colours

ex. 3 - grey colour surrounded by white, grey and black colours

ex. 4 - arrangement of ready-made elements for relativism of colours - with the possibility of using colour backgrounds obtaining various reds in spite of using the same red element; the same with green and grey elements.

ex. 5. - control exercise on the subject: "Still life: Blue bottles surrounded by green colours"

- drawing exercises:

ex. 1 - relativism of the shape of lines

ex. 2 - relativism of the thickness of lines

\footnotetext{
${ }^{6}$ The world "ungo" is a neologism, so that the children did not associate it with any schematic drawings of people or places known to them, like Smurfs, Donald Duck etc., but used their imagination.

${ }^{7}$ Elements of red were hung at various heights and differentiated in respect of shape, so that the rule of the fixed perception of colours and shapes could not work.
} 
ex. 3 - relativism of the size of lines

ex. 4 - linear illusions - perceiving lines exposed to linear illusions

ex. 5. - control exercise on the subject: "The battle of waves"

- sculpture exercises:

ex. 1 - relativism of the shape of solids depending on patterns on the surface and kinds of surface

ex. 2 - relativism of the shape of solids depending on the shape of surrounding solids

ex. 3 - relativism of the size of solids depending on the size of surrounding ones

ex. 4 - relativism of the shape and size of a group of solids in arrangements of similar and contrasting shapes

ex. 5. - control exercise on the subject: "The suspended town"8

In the experimental group after every completed set of exercises (that is, after each of the three parts of the experiment) for a given "visual quality", the children were presented with examples of works of art in the form of slides. Their attention was drawn to the ways artists solved artistic problems, which they perceived in perceptual standards and represented artistically. This offered an opportunity to confront their own visualartistic experiences with the "perception" and experience of artists.

\section{Analysis of the test results}

- The adopted assumptions of the independent variable were the visual qualities that occurred in the formulas visual (colour, lines, solids).

- The dependent variable is the children's artwork (painting, drawing, sculpture).

I obtained the following indicators for the analysis of the paintings:

1. the number of colours differentiated in terms of asset,

2. the number of colours differentiated in terms of saturation,

3. the number of colours varying in tone.

Indicators for analysis of the drawings:

1. the number of lines varying in terms of the types of lines,

2. the number of lines differentiated in terms of length,

3. the number of lines in terms of directions (vertical, horizontal, digonal).

Indicators for sculpting exercises:

1. the number of solids differentiated in terms of types of solid,

2. the number of solids differentiated in terms of the invoice,

\footnotetext{
${ }^{8}$ The success of children from the experimental group in the sculpture exercises consisted of modelling full solids by adding or taking away the material. The children worked out correct methods of modelling the solid by themselves du-
} 
3. number of lumps of various size,

4. the number of solids differing in thickness,

5. the number of solids differentiated in terms of directions (horizontal, vertical, diagonal).

I put the question: Does the formation of visual perception affect the quality of the work of children? and formulated the hypothesis: The deliberate and skilful shaping of visual perception using visual qualities (experimental programme) causes of action enables children to become more artistically aware, following the development of their artistic skills.

The task of the children was like richest (varied qualitatively and quantitatively) artistic interpretation of visual quality perceived in patterns of perception.

The maximum number of points for each art exercise was 13 and corresponded to the number in the formula of visual perceptual.

To verify the research hypothesis, if two attempts cone from the same population I used a nonparametic test the significance of differences Kolmogorov - Smirnov test for independent samples with ordinal scale.

A quantitative analysis of each child's artistic work was carried out using the benchamrks in an exercise on the part of the experiment.

Two experimental groups participated in the study along with one control group. The author carried out the exercises in both of the experimental groups.

Statistical verification of the test results confirmed the experimental hypothesis assumptions demonstrating a relationship between the evolution of visual perception in children and the quality of their works of art. The assumptions lying behind the research and verification of the results have been described and presented in the book: Shaping of visual perception as a stimulator of artistic activities of the Child. ${ }^{9}$

\section{CONCLUSIONS}

The experiment demonstrated that the children, using their perceptual experiences in artistic activities created deliberate, interesting and artistically mature compositions. It is worth mentioning that the artistic work of the children from the experimental groups was not typical of children in this period of development. They revealed high sensitivity to visual qualities and artistic values corresponding to them.

Observing the great emotional and mental involvement of the children during classes, I came to the conclusion that this kind of stimulation of creative activities may have a therapeutic influence on their ability to concentrate, as well as on their mental and manual abilities.

The results achieved in the experimental groups allow one to believe that the triad: perception - vision - visual perception is a gradual learning process. Shaping visual per-

\footnotetext{
${ }^{9}$ Szuścik, Kształtowanie percepcji wzrokowej jako stymulator działań plastycznych dziecka. Uniwersytet Śląski Filia w Cieszynie Cieszyn 1999.
} 
ception as a stimulator of artistic activities, which was the subject matter of the above described pedagogical natural experiment is a method of developing the ability of analytic perception of visual qualities.

The result of the artistic activities of children in the experimental group stimulated creativity.

The experiment allows the conclusion to be drawn that there are unused creative abilities in children, thus indirectly it encourages stimulation of their artistic activities during didactic classes.

The study that was carried out could make a good starting point for creating a new pedagogical concept for stimulating artistic activities in children. This stimulation "opens up" the way for children to experimenting in the field of visual and artistic problems, ensuring possibilities for developing their own structures of particular visual qualities. It can be supposed that it will remain a structure functioning as a model comprising the three codes: enactive, icon and symbolic ones. Children will enrich it along with new visual experiences. Summing up, it can be said that "seeing" visual qualities developed in children will be transferred to objects known to them, which they will get to know anew. This will develop their aesthetic perception at the same time.

As visual perception determines the character and quality of artistic activities in children in such a significant way, it seems worth trying to revise the system of developing their artistic activities that has been used so far in art education.

This should be based on psychological knowledge concerning the relationship between visual perception of visual models, forming a specific alphabet of form and the elements of artistic creation.

Analysis of the results of the study was carried out with the technique of analysing the products, that is artistic works of children produced during the experiment - quantitative and qualitative analysis of the works. These products are documents intentionally produced by the children.

\section{REFERENCES}

Arnheim, R. (1978). Sztuka i percepcja wzrokowa. Psychologia twórczego oka. Warszawa: WAiF.

Balley, S., Witwicki, T. (1948). Barwa, kształt, wielkość w spostrzeżeniu dzieci. Psychologia Wychowawcza 3/4.

Bruner, J.S. (1978). Poza dostarczone informacje. Studia z psychologii poznania. Warszawa: PWN .

Brzeziński, J. (1975). Metody badań psychologicznych w zarysie. Poznań: UAM. Gombrich, E.H. (1981). Sztuka i złudzenie. Warszawa, PIW.

Gregory, R.L. (1971). Oko i mózg. Psychologia widzenia. Warszawa: PWN . 
Hebb, D.O. (1949). The organisation of behavior. A neurophysiological theory. New York:

Willey.

Hebb, D.O. (1969). Podręcznik psychologii. Warszawa: PWN.

Hochberg, J. (1970). Percepcja. Warszawa: PWN.

Ingarden, R. (1966). Przeżycie - dzieło - wartość. Kraków: WL.

Ingarden, R. (1957). Studia z estetyki. T.1. Warszawa: PWN.

Ingarden, R. (1966). Studia z estetyki. T.2. Warszawa: PWN.

Ingarden, R. (1970). Studia z estetyki. T.3. Warszawa: PWN.

Konorski, J. (1978). Zasady neurofizjologicznych mechanizmów percepcji. Studia Psychologiczne, 9.

Lindsay, P.H. Norman, D.A. (1984). Procesy przetwarzania informacji u człowieka. Warszawa: PWN.

Lowenfeld, V. Brittain, W.L. (1977). Twórczość a rozwój umysłowy dziecka. Warszawa: PWN. Młotkowski, J. (1992). Psychologiczne aspekty przetwarzania informacji wizualnej. W M.

Ostrowski, (Red.), Informacja obrazowa. Warszawa: WNT, s. (421-469).

Piaget, J. (1966). Studia z psychologii dziecka. PWN, Warszawa.

Strzałecki, A. (1969). Wybrane zagadnienia psychologii twórczości. PWN, Warszawa.

Szuman, S. (1927). Obserwacje dotyczące tzw. synkretycznego spostrzegania u dziecka.

Polskie Archiwum Psychologii, T. II nr 1.

Szuman, S. (1927). Sztuka dziecka. Psychologia twórczości rysunkowej. Warszawa: Książnica - Atlas.

Szuman, S. (1927). Badania nad rozwojem apercepcji i reprodukcji prostych kształtów u dzieci. Poznań: Wyd. Towarzystwa Przyjaciół Nauk.

Szuman, S. (1985). Geneza przedmiotu. W S. Szuman, Dzieła wybrane. , s. (20-41), T.1, Warszawa: PZWSiP.

Szuścik, U. (1999). Kształtowanie percepcji wzrokowej jako stymulator działań plastycznych dziecka. Cieszyn: Uniwersytet Śląski Filia w Cieszynie.

Wyburn, G.M., Pickford, R.W. (1970). Zmysły i odbiór wrażeń przez człowieka. Warszawa: PWN.

Wygotski, L.S. (1971). Wybrane prace psychologiczne. Warszawa: PWN.

Wygotski, L.S. (1978). Narzędzie i znak w rozwoju dziecka. Warszawa: PWN.

Zaczyński, Wł. (1976). Zasady badań eksperymentalnych. Warszawa: PWN.

Corresponding author at: Urszula Szuścik, Department of Ethnology and Educational Science in Cieszyn, University of Silesia, ul. Bielska 62, 43-400 Cieszyn, Poland Email: ulaszus@poczta.onet.pl

(C) Copyright by Faculty of Pedagogy and Psychology, University of Bialystok, 20 Swierkowa St., 15-328 Bialystok, Poland tel. +48857457283 